\title{
Research on Operation Mechanism of Civil-military Integration Equipment Support Supply Chain
}

\author{
Chang Feng Zhou ${ }^{1, a}$, Yan Liu ${ }^{2}$ \\ ${ }^{1}$ National University of Defense Technology, School of Social Sciences and Humanities, Hunan Province, China \\ ${ }^{2}$ National University of Defense Technology, School of Information System and Management, Hunan Province, China
}

\begin{abstract}
High-tech local wars under conditions of informatization is becoming increasingly dependent on the security of weapons and equipment, and civil-military integration equipment support has become a trend. Civilmilitary integration equipment support chain construction vigorously, must be starting from the strengthening of the top-level planning decisions, building the civil-military coordination and restraint mechanisms and establishing efficient incentives and effective oversight mechanisms to ensure the performance of various support tasks, and to enhance the equipment support ability to achieve "fast, accurate, and efficient" goals.
\end{abstract}

\section{Introduction}

Construction of integrated military and civilian equipment support supply-chain is a main direction and trends to adapt the development of equipment support, a long-term mechanism must be establishing to guarantee its continued stable operation. Under the conditions of market economy, it is necessary for promoting integrated military and civilian equipment support that to gradually establish and perfect the equipment support in integrated military and civilian planning and decision-making mechanisms, constraints on coordination mechanisms, incentives and supervision and evaluation mechanism, strengthening of integrated military and civilian equipment support running order.

\section{Strengthen top-level planning decisions}

Construction of integrated military and civilian equipment supply chain, is to break the "behind closed doors" stereotype, consider military equipment support issues in a strategic point, Overall plan military equipment support resources, and set up equipment support systems which adapt to the times.

\subsection{Focused on top-tier design}

Promoting the construction of integrated military and civilian equipment supply chain, is related to the country as a whole, must reflect the will of the State. Integrated military and civilian equipment support supply-chainbuilding involves rational allocation and use of national scientific and technological resources, involving national defense industrial base and the Foundation of national

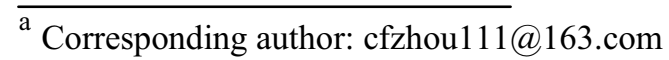

economy adjustment and harmonization of a number of important issues, such as, must stand on the national level, planning at the top, and on the basis of a unified deployment, development goals and concrete measures. Planning should be looking to the longer term, based on reality, and the development of China's market economy, enterprise level, equipment support supply chain status match, and to adjust the integrated military and civilian support supply chain development to ensure integrated military and civilian equipment support right direction and realize sustainable development of construction of equipment support supply chain.

Design at the top level, it is necessary to change the traditional military-industrial-military-separation model, must be addressed through macro-control measures, on behalf of the State and the Ministry of defence, issued a series of laws, regulations and standards. Standing at the height of the laws, regulations and standards, it is need to establish and improve the integrated military and civilian weapons research, production, support system, and then the construction of integrated military and civilian equipment supply chain is promoted.

\subsection{Improve the protection implementation plan}

Equipment support in accordance with the timing can be divided into the usual equipment support, emergency equipment and equipment support in wartime. Therefore, during the construction of integrated military and civilian equipment supply chain, it is need to develop appropriate equipment support processes to improve the integrated military and civilian equipment support supply chain efficiency and effectiveness.

At the time of equipment support in peacetime, its main task is to complete military training in peacetime security, military exercises and weapon experimental 
support, therefore, in order to comply with the laws of the market, full realization of materiel support of military, economic and social benefits. While retaining core support capacity, non-core support capacity will gradually be handed over to the local Security Department. According to the characteristics of high-tech equipment and equipment support needs, it is need to strengthen the construction of military equipment support, and comprehensive utilization of resources and Manpower, and achieve coordinated development of military resources and effective integration. Compared with traditional war under the condition of informationization war strength, because of high scientific and technological content, equipment materials consumption, the timeliness requirements of the equipment support are relatively high. Wartime or emergency equipment is mainly done during the war or State of emergency material allocate support, equipment, technical support and equipment battle damage repair services. Therefore, at the time of war or emergency, with time priority, it is need to strengthen the administrative plan, supplemented by market mechanisms, ensure equipment support translation quickly and efficiently to ensure weapons and equipment in the best tactical and technical state. While military and civilian integration during the construction of equipment support supply chain, it should pay attention to in peacetime, wartime demand peacetime construction, usually supporting wartime, peacetime and wartime, combining emergency equipment support needs.

\section{Build coordination mechanism}

Communication and coordination mechanism is the lubricant of integrated military and civilian equipment running smoothly, it can strengthen the correlation between organizations, strengthen the exchange of information on military and security contractors, for the implementation of integrated military and civilian equipment support supply chain provide good running condition.

\subsection{Enhanced security of supply chain control}

Enhancing coordination and control is a key that to ensure the integrated civilian-military equipment support running smoothly and effectively. Military-civilian coordination mechanism is the means to meet the needs of military and social logistics, from the vertical (strategic, operational and tactical levels) and horizontal (collection, storage, transportation, packaging, distribution, and so on) in two dimensions, links, military and logistics functions, tasks and link up with organizations to achieve synchronous operation, seamless connectivity. Establishment of a coordination mechanism, is the thought of modern logistics system integration, supply chain optimization, effective ways to improve safeguards effectiveness and efficiency of the military equipment, to build an integrated civilian-military essential requirements of equipment support supply chain. Both army and civilian should established exchange mechanism, regularly carried out experience exchange, and theory discussion, and business training, activities, equipment guarantees management sector to and national government procurement related sector strengthening contact, established normal coordination mechanism, and regularly joint system and situation informed system, exchange information, clear the work of points and focus of civil-military integration equipment support, consult and host daily jobs of civil-military integration equipment support system construction, Coordinate and solve major problem of civil-military integration equipment support construction.

\section{2 establishing the concept of supply chain management}

It is need to establish a supply chain process management concept for building military-civilian coordination mechanisms. Modern military logistics is connected to suppliers and force users, set the collection, storage, transport, distribution and other links in one equipment support supply-chain. Using the synchronous response time of supply chain management, supply chain management, demand of logistics entities of the information shared in real time makes the traditional military-logistics system, the link from "serial" to the "parallel" mode of synchronization protection activities of the Organization in order to optimize the supply chain process and shorten reaction time, improve the efficiency of logistics support. It is need to form a focus on needs of joint security forces for building a coordination mechanism. For fast to meet customer needs, the Americans proposed the concept of focusing on logistics, emphasized the integration of land and building, before and after integrated, multidimensional combination, focusing on needs of security mode. The idea is in line with the development trend of modern logistics, is the direction of military civil-military integration of military logistics support system. Building a coordination mechanism should be based on national mobilization of institutions at all levels, strategic, operational and tactical levels and coordinated logistics support force, fully coordinated air, sea and land forces logistic support forces to form focused cross-hierarchy of needs support, regional security, across services using federated security posture.

\subsection{Implementation of the access and exit of private enterprises system}

Establishing the system of the access and exit of private enterprises is a guide and control for army on private enterprises participating equipment support, to ensure the safe and effective operation equipment support in integrated civilian-military efforts. On one hand, it is need to set up strict access restriction mechanism, strict qualification issue. Private enterprise participates in equipment support must be in accordance with the procedure provided for critical review, in line with the National Defense Science and technology industry Council "license" system and the army's "qualification system" in order to assume control of weapon and equipment development and production qualification. Note Verify that private enterprise has ability to bear civil 
liability independently, have good credit and a sound quality assurance system, and has the capacity to meet conditions and equipment development and production contract. Qualification attestation contained in qualified manufacturers list, based on preference for performance specifications for ordering objects, dynamic management mechanism. The other hand, it needs the flexible control of the companies. According to the number of companies, supply of equipment, maintenance of quality and other indicators, military can forecast enterprise development, and warn against the unqualified enterprises, and has time for re-employment qualified enterprises. It also can help enterprises make industrial transfer and exit decisions accordingly. At the same time it is need to increase the exit supervision. Underwriting companies exit the market for equipment support, first of all, it is need to be logged off license, and approved by the licensing administration office logs off before they can quit. It is need to emphasis on exit links of coordinated, timely resolve disputes on both sides to ensure a seamless transition. It is also need to perfect exit regulations, increase penalties for violations out of businesses, and earnestly safeguard the legitimate rights and interests of the military.

\section{Establish an efficient incentive mechanism}

In the practice of equipment support, civil-military integration relate to property rights, asset specificity, asymmetric information issues will have a complex representation. This requires from institutional settings, environments, and conditions of analysis, the choice of means of application of concrete ideas, designing effective incentive mechanisms to promote civil-military integration of equipment support supply chain.

\subsection{Implementation of property right incentive}

Incentive nature, remains a traditional clear property rights and reduce system cost, as it is in the present social environment institutional basis to attract collectors and private enterprises to enter the field of equipment support of the most basic and most effective approach. Our contractual system of equipment support domain is still not perfect, relationship economy occupies a certain position, only completing compact economy as soon as possible, reducing relationship economic, specific incentive measures, can clear ownership and accountability, strict protection. For any business, reasonable property and freedom of contract are prerequisites for efficient economy, so the incentive is key part of integrated military and civilian equipment support incentive mechanism.

Ownership incentive, to contract the economy is the most important economic transformation, it is a process of institutional change. In theory, the system approaches into induced institutional change and changes of compulsory system in two ways. Response induced institutional change is a group of people by the institutional imbalance caused by chance, of the spontaneous change: related groups is a spontaneous reaction to the system unbalanced, consistency of its greatest advantage is based on the agreed principles, in line with the practical environment of institutional change, so it is an effective institutional change. Changes of compulsory system refers to the system of Government by decree imposing the changes. Mandatory system changes state or Government is the owner, its biggest advantage is the ability to rely on its own force, reducing system changes cost and implementation costs, so it is a low consumption of system changes. Due to limited rationality and opportunism, relationship between them should be complementary rather than alternative. Civilmilitary integration equipment support of property incentive, should take combined principles including induced institutional changes and compulsory institutional changes, the specific measures should includes clear property and protection property in legal regulations, simplify application program, and reduce system cost, clear right range of the institutions and sectors to avoid property erosion, establish bid competition mechanism based on market for relies on of "public, justice, and fair", encourage enterprises to access and obtain project contractualization, standardization and scientific, reduce the costs of established information network center, messaging and information search.

\subsection{Strengthening specific investment incentives}

Incentive consideration is the protection of property rights, and enable enterprises to participate in equipment support initiative. Compensation for asset specificity is asset specificity to enterprises, particularly compensate for additional losses. Case of particularity in the equipment industry, it is need to help enterprises recover sunk costs which discourage companies to participate in integrated military and civilian equipment support. This is the most important private investment incentives besides of the property right motivation.

Equipment support of asset specificity will make doubts, the military and the Government should be based on the value of compensation incentives to solve this problem. Setting up incentive program is to make the private enterprises to select equipment support trades for utility no less than other options. Therefore, private asset specificity should be affected by extra costs or may in the future to compensate for losses suffered by. So-called extra costs, are sunk costs after private enterprises entering the field of equipment support. So-called loss refers to military decision making changes and other risks of asset specificity losses of enterprises. So the military not only pays for the end product--support results, but also for intermediate goods--in the process of investment and personnel training. In addition, military enterprises for the production of equipment and parts should be purchased tangible assets, for those hard to projectspecific test for weapons and production equipment, the military should also invest in and, in some cases, make a commitment in the contract, if the project is cancelled, the funds paid.

Compensation may be special fund and can also be incorporated into the price. In general, with the development of China's socialist market economy, the growing maturity of the price formation mechanism and 
prediction of price increase, compensation incorporated into the price is more reasonable. Equipment price incentive pricing models should be limited, which divided into the standard price and incentive price. Standard price is refers to equipment products tangible entity in military research production process, which determined through negotiations before contract signed. Incentive price is to guarantee equipment products research production and procurement task of smooth completed and need sharing of costs and should gets of profit award and compensation, which determined in contract implementation process through constantly annual negotiations. Risk compensation should be primarily determined in connection with assets dedicated risk. After assessing the expected of sunk costs and uncertainty loss because of asset specificity, risk compensation price structure can be set.

\section{Establishing effective monitoring mechanisms}

Oversight mechanisms are necessary constraints for integrated military and civilian equipment support chain operation, effectively guarantee the implementation of contracts for equipment support, promoting quality management contractor for equipment support. In the process of implementing equipment support, it is necessary to supervise on every step strictly, especially for equipment support services contractor in the market of rent-seeking behavior, service quality of equipment support and task completion deadlines.

\subsection{Avoiding the contract of rent-seeking behavior}

From the perspective of institutional economics and public choice theory, the key to harness rent-seeking behavior is to perfect institutional size and constraint to achieve resource allocation legalization, marketization and socialization. Based on the equipment contractor's cost-benefit comparison, establishing the new system by increasing rent costs and reduced rent income, rentseeking of net income is less than the profit-seeking, thereby adjusting the contractor bias.

For equipment support services contractor in the market to give up rent-seeking behavior, consisting of a full range of supervision is set up to avoid no oversight. Headquarters based on organization structure of equipment support supply-chain complexity and number of personnel, consider setting up a level or two-level procuratorial bodies, its functions and powers, to be defined clearly, equipment support the Supreme authority. In general, procuratorial authorities are responsible for safety, production and quality management as well as the implementation of the system, monitoring, evaluation and feedback.

\subsection{Overcoming moral hazard and adverse selection}

So-called asymmetry is unequal information at the disposal of the parties. Prior consequences adverse selection of information asymmetry and asymmetry of information can result in moral hazard problems. Both adverse selection and moral hazard, will make the market allocation of resources loss of Pareto optimality properties. During construction process of integrated military and civilian equipment support supply chain, army private is always better to know and control for military forces, but worse for private enterprises. Contractor know its own development and production and support capabilities, management level, operator quality, preferences more clearly than in the military. Private contractors will Sign the contracts by using the advantage of the information, and intentionally concealing adverse information on the contract, which may cause problems such as adverse selection and moral hazard. In order to avoid adverse selection and effectively to avoid moral hazard, it must complete information as far as possible to overcome the asymmetry of information.

So, selecting enterprise cannot just requirements cost minimum, also to many considerations. After the bidding and before signing the contract, military should check the support enterprise for qualification review, see its quality system and confidential procedures whether in place, technology and economic strength can completed military proposed of equipment support requirements, whether has similar experience of civilian support, military also can through early demonstrates validation, and simulation test and end try, variety means active reveals enterprise information. All this contributes to good information transmission channels, enabling the military to screen different types of businesses, to overcome the harm caused by adverse selection and moral hazard risks to civil-military integration.

\section{Conclusion}

The construction of operation mechanism is the prerequisite and fundamental guarantee for implementing integrated operation of weapon equipment research, production, storage, and supply, and achieving supply goals of "rapid, precise and efficient" security. Only by strengthening the normal order of integrated military and civilian equipment support chain, it can promote sound and fast development of integrated military and civilian equipment support to ensure that military and civilian integration equipment support can running quickly, efficiently and smoothly.

\section{References}

1. Li Qingquan, Wang Bing, Liu Xuyang . Study on the operational mechanism of equipment material supply chain $[\mathrm{J}]$. Logistics and purchasing in China, 2011,07:76-77.

2. Shuang Haijun. Weapons monitoring and incentive mechanism in procurement [D]. Chongqing University, 2010.

3. Shang Li, Dong Peng, Wu Wanqiu. Research on equipment support chain mechanism under the condition of Informationization war $[\mathrm{J}]$. Logistics technology, 2009,01:148-150. 
4. Straube F,Ma S H,Bohn M. Internationalization of logistics systems how Chinese and German companies enter foreign markets[M].Berlin:SpringerVerlag,2008.

5. Simatupang T M,Sandroto I V,Lubis S B H. Supply chain coordination in a fashion firm[J].Supply Chain Management:An International Journal,2004,(03):256-268.

6. Fu Y,Piplani R. Supply-side collaboration and its value in supply chains[J].European Journal of Operational Research,2004,(01):281-288.

7. Frascatore M R,Mahmoodi F. Long-term and penalty contracts in a two-stage supply chain with stochastic demand[J].European Journal of Operational Research,2008.147-156.

8. Mathur P P,Shah J. Supply chain contracts with capacity investment decision:Two-way penalties for coordination[J].International Journal of Production Economics,2008,(1):56-70.

9. Gurnani H,Gerchak Y. Coordination in decentralized assembly systems with uncertain component yields $[\mathrm{J}]$.European Journal of Operational Research,2007,(1):1559-1576. 